\title{
The nexus between consumption of biofuels and economic growth: an empirical evidence from Brazil
}

\section{O nexo entre consumo de biocombustiveis e crescimento econômico: Uma evidência empírica do Brasil}

\author{
1 Matheus Koengkan matheuskoen@hotmail.com.br
}

1 Mestrando em Economia na Universidade da Beira Interior (Covilhã Portugal), Pós-graduado em Controladoria e Finanças pela Universidade Federal Fluminense UFF (2015), Graduado em Ciências Contábeis pelo Centro Universitário de Volta Redonda UNIFOA (2013).Atualmente pesquisador nas áreas da Economia da Energia e Finanças Empresariais na Universidade da Beira Interior.

\begin{abstract}
This study investigates the nexus between consumption of biofuels and economic growth in Brazil during the period of 1990 to 2015 . The vector autoregressive (VAR) was applied. The preliminary tests proved the presence of multicollinearity and the existence of unit root in the variables. The results of VAR model indicated the existence of a bidirectional relationship between consumption of biofuels and economic growth, consumption of oil and economic growth, and consumption of biofuels and oil. These results are an opportunity for policymakers to change the energy matrix with the introduction of more renewable energy sources in order to reduces environmental degradation.
\end{abstract}

\section{Keywords}

Energy economics, Renewable energy, Biofuels, Econometric, Nexus.

\section{Resumo}

Este estudo investiga o nexo entre o consumo de biocombustíveis e o crescimento econômico no Brasil duranteoperíodo de 1990a2015. Ovectorautoregressive (VAR) foi aplicado. Os testes preliminares provaram a presença de multicolinearidade e a existência de raiz unitária nas variáveis. Os resultados do modelo VAR indicaram a existência de uma relação bidirecional entre consumo de biocombustíveis e crescimento econômico, consumo de petróleo e crescimento econômico e consumo de biocombustíveis e petróleo. Esses resultados são uma oportunidade para os decisores políticos mudarem a matriz energética com a introdução de mais fontes de energia renováveis para reduzir a degradação ambiental.

\section{Palavras-chave}

EconomiadaEnergia, Energiarenováveis, Biocombustíveis, Econometria, Nexus.

\section{Como você deve citar?}

KOENGKAN, Matheus. The nexus between consumption of biofuels and economic growth: an empirical evidence from Brazil. Cadernos UniFOA, Volta Redonda, n. 35, p. 87-98, dez. 2017. 


\section{INTRODUCTION}

The great investments in renewable energy sources in the last two decades in Brazil can be attributed to a number of factors. The volatility of oil prices, the national energy demand and the environmental consequences of carbon dioxide emissions are contributing factors to the current interest in renewable energy sources (Apergis and Payne,2010). Moreover, in front of these factors, the governments have stipulated policies in order to stimulate the production and consumption of renewable energy sources like biofuels, that started in 1977 with the ethanol-use mandate, which required a $4.5 \%$ percent blend of ethanol to gasoline and $25 \%$ percent throughout the years (USDA, 2015). Brazil is the second-largest producer of Biofuels after the USA and has been the pioneer in developing integrated biofuel policies and infrastructure (Langeveld et al. 2014). Indeed, the biofuels production in Brazil soared $85 \%$ in 2015 to more than 4 million cubic meters and an installed capacity of 7.3 million cubic meters. Furthermore, the capacity production increased $103 \%$ since biodiesel blending mandates were first introduced in 1977 (Sapp,2016).

The central question of this article is: what is the directional relationship between consumption of biofuels and economic growth in Brazil? The main aim of this study is to investigate the directional relationship between consumption of biofuels and economic growth in Brazil over the period of 1990 to 2015 , using a vector autoregressive (VAR) method introduced into empirical economics by Sims (1980). The causality between consumption of renewable energy and economic growth has been investigated by several authors. For instance, Al-Mulali et al. (2016) investigated the impact of consumption of biofuels on economic growth in Brazil over the period from 1980 to 2012, using the Autoregressive Distributed Lag (ARDL). The authors identified the existence of feedback relationship between the variables. Cetin (2016) explored in seven European countries the relationship between consumption of renewable energy and economic growth over the period of 1992 to 2012. The author used the heterogeneous panel data as methodology. The empirical results confirmed the existence of a long-run relationship between consumption of renewable energy and economic growth. Belaïd and Zrelli (2016) examined in Mediterranean countries the nexus between consumption of renewable energy, $\mathrm{CO}_{2}$ emissions over the period of 1980-2012. The authors utilized the panel unit root tests co-integration as method. The results indicated the existence of short-run bidirectional causality between economic growth, consumption of renewable energy, and $\mathrm{CO}_{2}$ emissions. Acikgoz et al. (2016) studied the impact of consumption of renewable energy on economic growth inrich countries over the period from 1990 to 2012. The authors utilized the panel co-integration and ARDL model. The results pointed that the consumption of renewable energy has a positive impact on economic growth. Koçak and Şarkgüneşi (2017) investigated the relationship between consumption of renewable energy and economic growth in thenine Black Sea and Balkan countries for the period of 1990 to 2012. The authors used the panel co-integration as method. The results pointed that there is a long-run relationship between consumption of renewable energy and economic growth and the consumption of renewable energy has a positive effect on economic growth. Terzi and Pata (2016) investigated in Turkish economy the relationship between economic growth and consumption of oil in a period from 1974 to 2014and the causality test, the Engle-Granger, and GregoryHansen co-integration models were used. The authors found that there is non-long-term co-integration between the level of economic growth and oil consumption level. Choi and Yoo (2016) studied in Brazil the causal relationship between consumption of oil and economic growth.The Granger-causality test was used as methodology. The results showed the existence of bidirectional causality between consumption of oil and economic growth in Brazil. Shahid et al. (2014) investigated the nexus between consumption of energy and economic growth in Brazil over the period of 1971-2010. The authors used the OLS regression as methodology. They found that the consumption of energy has a negative impact on economic and financial activities in Brazil. 
The study of this theme is important for the following reasons: it is necessary to understand the real impact of consumption of biofuels on economic growth. Also, there are few studies in the literature which investigate the impact of renewable energy sources on economic growth in Brazil. Additionally, the choice of Brazil is due to the fact that the country is a pioneer in the development of this kind of source of energy and the consumption of biofuels is in constant growth (See Figure 1).

Figure 1. Consumption of biofuels between 1990-2015

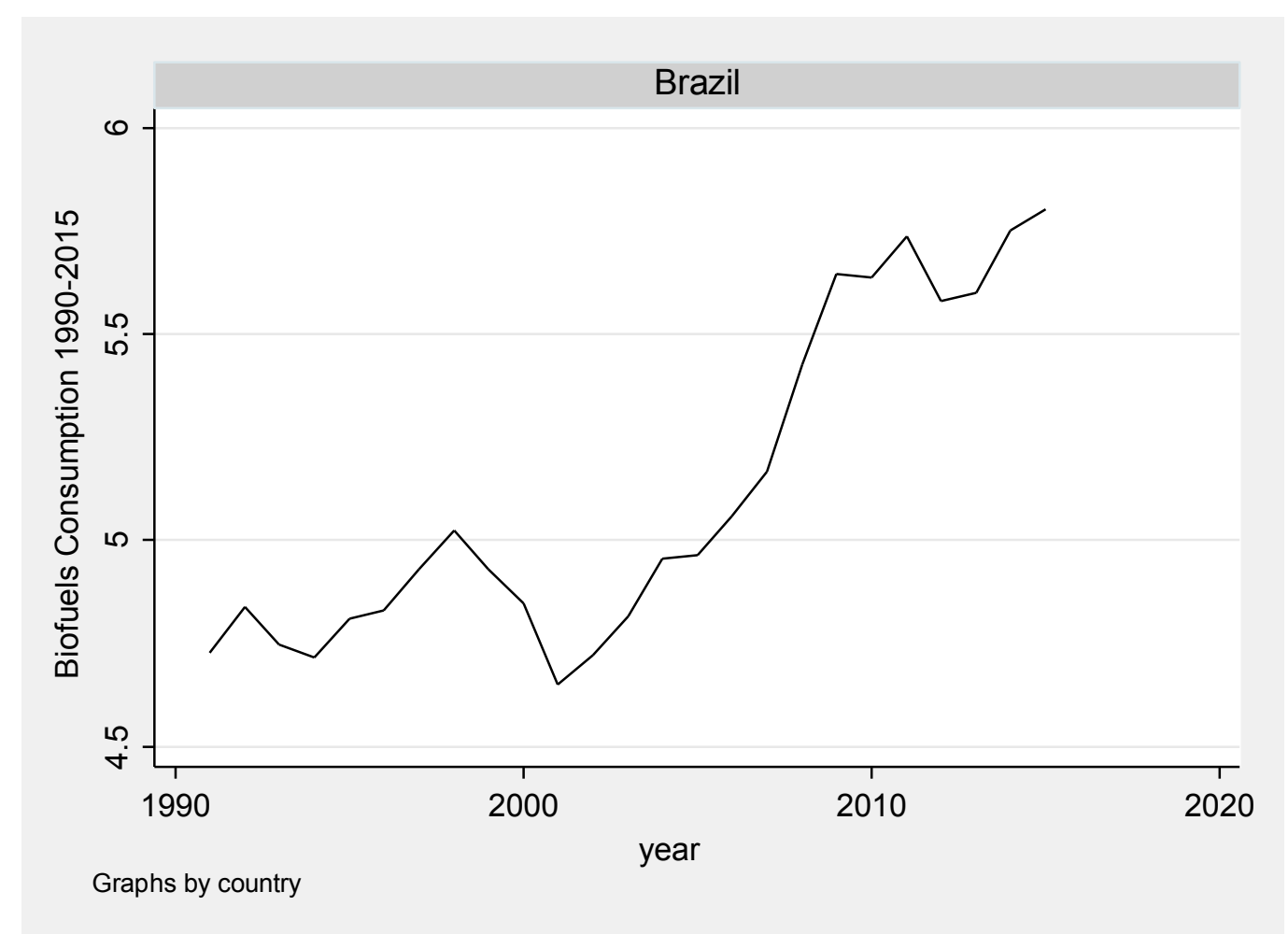

Notes: The Stata command $x$ tline was used.

This article is organized as follows: Section 2, presents the material; Section 3, presents the method; Section 4, the preliminary tests; Section 5, the empirical results and discussions and finally, Section 6, presents the conclusions.

\section{MATERIAL}

To analyze the relationship between consumption of biofuels and economic growththe following variables were used: (i) Gross Domestic Product (GDP); (ii) Consumption of biofuels; (iii) Consumption of oil. Table 1, shows the name, definition, sources, and summary statistics of variables. 
Table 1. Variables description and summary statistics

\begin{tabular}{|c|c|c|c|c|c|c|c|}
\hline Variables & Definition(s) & Source (s) & Obs & Mean & Std. Dev & Min & Max \\
\hline LnGDP & $\begin{array}{l}\text { GDP in per } \\
\text { capita. }\end{array}$ & $\begin{array}{l}\text { The World } \\
\text { Bank } \\
\text { Database } \\
(\text { WBD })^{2} \text {. }\end{array}$ & 26 & 8.8996 & 0.1374 & 8.7068 & 9.1289 \\
\hline LnBiofuels & $\begin{array}{l}\text { Biofuels } \\
\text { consumption } \\
\text { in thousand } \\
\text { tonnes of oil } \\
\text { equivalent. }\end{array}$ & $\begin{array}{l}\text { BP Statistical } \\
\text { Review World } \\
\text { Energy }{ }^{3} \text {. }\end{array}$ & 26 & 9.0541 & 0.4135 & 8.5614 & 9.7777 \\
\hline LnOil & $\begin{array}{l}\text { Oil } \\
\text { consumption in } \\
\text { million tonnes. }\end{array}$ & $\begin{array}{l}\text { BP Statistical } \\
\text { Review World } \\
\text { Energy. }\end{array}$ & 26 & -11.8281 & 0.3760 & -12.3813 & -11.3175 \\
\hline
\end{tabular}

Notes:The prefixes ("Ln") denotes variables in the natural logarithms; The Stata command sum was used.

To control the population disparity, all variables were transformed in percapita values. Moreover, the Stata 15.1 software was used for the econometric analysis. Then, before the VAR regression, it is necessary to test the robustness of variables. For this, the determinant of the correlation matrix, Bartlett's test for sphericity (Bartellet, 1950), and Kaiser-Meyer-Olkin measure of sampling adequacy (Kaiser 1974) were applied.

The determinant of the correlation matrix is equivalent 1.0 if all correlations equal 0 ; otherwise, the determinant will be less than 1. Moreover,the Bartlett's test computes the determinant of the matrix of sums, from the intercorrelation matrix. The null hypothesis of this test is that the variables are not intercorrelated (Bartellet, 1950). The Kaiser-Meyer-Olkin Measure of Sampling Adequacy is an index to associating the magnitudes of correlation between the coefficients (Kaiser 1974). This test follows the following parameters to indicate that a factor analysis of the variables: (i) $90 \%$ or above is excellent; (ii) $80 \%$ or above is meritorious; (iii) $70 \%$ or above is middling; (iv) $60 \%$ or above is mediocre; (v) $50 \%$ or above is miserable, and (vi) below $50 \%$ is unacceptable. Table 2 , shows the results of robustness of the composite variable test.

Table 2. Test of robustness of the composite variable

\begin{tabular}{ll}
\hline Determinant of the correlation matrix & $=0.017$ \\
Det & \\
\hdashline Bartlett test of sphericity & $=94.514$ \\
Chi-square & $=3$ \\
Degrees of freedom & $=0.000$ \\
p-value & \\
\hline Kaiser-Meyer-Olkin measure of sampling adequacy & $=0.623$ \\
KMO &
\end{tabular}

Notes: The Stata command factortest was used.

The result of the determinant of the correlation matrix indicated that all the measures are correlated because the value of the determinant of the correlation matrix is 0.017 . The Bartlett test of sphericity indicated that the variables are not intercorrelated. Moreover, the Kaiser-Meyer-Olkin Measure of Sampling Adequacy indicated that the factor analysis of the variables is mediocre due to the KMO is $0.623>60 \%$.

2 The World Bank Database (WBD). Available in:<http://data.worldbank.org/>.

3 BP Statistical Review World Energy. Available in: <http://www.bp.com/en/global/corporate/energy-economics/statistical-review-of-world-energy.html>. 


\section{METHOD}

To investigate the nexus between consumption of biofuels and economic growth, the Vector autoregressive (VAR) model was used. This method was introduced into empirical economics by Sims (1980), since this method is a more flexible and tractable framework for analysing economic time series(Watson, 1994). Moreover, the VAR model used in this empirical analysis follow the specification of eq. (1):

$$
Y_{t}=\mathrm{A}_{1} y_{t-1}+\ldots+\mathrm{A}_{p} y_{t-p}+u_{t}
$$

Where $Y_{t}$ is endogenous variables (DLnGDP, DLnBiofuels, DLnOil), $\mathrm{A}_{i}$ are $(\mathrm{K} \times \mathrm{K})$ coefficient matrices for $i=1, \ldots, p$ and, $u_{t}$ is a K-dimensional process with $\mathrm{E}\left(u_{t}\right)=0$, and time-invariant positive definite covariance matrix $\mathrm{E}\left(u_{t}, u_{t}^{T}\right)=\sum_{u}$ (White noise).Moreover, before VAR regression, it is necessary to check the proprieties of the variables. For this, the preliminary tests as(i) Variance Inflation Factor (VIF)to check the multicollinearity (Hair et al. 2005); (ii) Augmented Dickey-Fuller test for unit root (Greene,2002) were computed. So, after the VAR regression the following test needs to be applied: (i) Lag order selection on estimation for identification of the best lag order to apply in the VAR regression (Lütkepohl,2005); (ii) Pairwise Granger Causality Wald test, to analyze the causal relationship between variables (Hoover,1988); (iii) Test for normally distributed disturbances that computes the series of statistics in contradiction of the null hypothesis according to which the disturbances in the VAR are normally distributed. The test for normally distributed disturbances calculates three statistics: kurtosis statistic, Jarque-Bera statistic, and skewness statistic (Jarque and Bera, 1987);(iv) Eigenvalue stability condition, to check stability condition of VAR estimates (Hamilton, 1994); (v) Wald lag-exclusion statistics, the hypothesis of this test is that the endogenous variables at the given lag are zero for each equation (Amisano and Giannini,1997). In the next section, the results of preliminary tests of VAR model will be shown.

\section{PRELIMINARY TEST}

The Variance Inflation Factor (VIF) and Augmented Dickey-Fuller test for unit root were used to check the characteristics of variables. Table 3, shows the results of VIF test and Augmented DickeyFuller test.

Table 3. VIF test and Augmented Dickey-Fuller test

\begin{tabular}{|c|c|c|c|c|c|}
\hline \multicolumn{3}{|c|}{ Variance Inflation Factor test (VIF) } & \multicolumn{3}{|c|}{ Augmented Dickey-Fuller test } \\
\hline Variables & VIF & 1/VIF & Test Statistic & $P-V a$ & \\
\hline LnGDP & n.a & n.a & -0.768 & 0.8283 & \\
\hline LnBiofuels & 2.80 & 0.3574 & -0.045 & 0.9547 & \\
\hline LnOil & 2.80 & 0.3574 & -0.939 & 0.7749 & \\
\hline Mean VIF & \multicolumn{2}{|c|}{2.80} & & & \\
\hline DLnGDP & n.a & n.a & -2.644 & 0.0842 & * \\
\hline DLnBiofuels & 1.07 & 0.9327 & -2.866 & 0.0494 & ** \\
\hline DLnOil & 1.07 & 0.9326 & -2.689 & 0.0760 & ** \\
\hline Mean VIF & \multicolumn{2}{|c|}{1.07} & & & \\
\hline
\end{tabular}

Notes:**, * denote the significance of $5 \%$ and $10 \%$ respectively; the prefixes ("Ln") and

("D") denote the variables in the natural logarithms and the first-differences of logarithms respectively; the Stata commands estatvif and dfuller with lags (1) were used. 
The value of the mean of VIF was $2.80 \%$ in the natural logarithms and at the first-differences $1.07 \%$ respectively. The means VIF is lower than the benchmark of $10 \%$, supporting the argument that multicollinearity is not a great problem in the model. Moreover, the Augmented Dickey-Fuller test for unit root was used. The null hypothesis is the existence of unit root in the variables. The result of this test indicated that all variables in the first-differences have a unit root. Additionally, after the VIF and Augmented Dickey-Fuller tests the VAR selection-order criteria was applied in order to identify the best lag-order to apply in the VAR model (Lütkepohl,2005). Table 4 shows the outcomes of selection-order criteria test.

Table 4. Lag order selection on estimation

\begin{tabular}{ccccccccc}
\hline Lags & LL & LR & df & P & FPE & AIC & HQIC & SBIC \\
\hline $\mathbf{0}$ & 97.379 & - & - & - & $1.6 \mathrm{e}-08$ & -9.4379 & -9.4087 & -9.2885 \\
$\mathbf{1}$ & 99.5797 & 4.4014 & 9 & 0.883 & $3.2 \mathrm{e}-08$ & -8.7580 & -8.6413 & -8.1605 \\
$\mathbf{2}$ & 104 & 8.8403 & 9 & 0.452 & $5.5 \mathrm{e}-08$ & -8.2999 & -8.0959 & -7.2545 \\
$\mathbf{3}$ & 113.597 & 19.194 & 9 & 0.024 & $6.3 \mathrm{e}-08$ & -8.3597 & -8.0681 & -6.8661 \\
$\mathbf{4}$ & 127.967 & 28.74 & 9 & 0.001 & $5.8 \mathrm{e}-08$ & -8.8967 & -8.5176 & -6.9550 \\
$\mathbf{5}$ & 171.084 & $86.234 *$ & 9 & 0.000 & $5.4 \mathrm{e}-09 *$ & $-12.3084 *$ & $-11.8419 *$ & $-9.9186 *$ \\
\hline
\end{tabular}

Notes: The Stata command varsoc was used.

The results of selection-order criteria test recommended the use of the lag-order (5). After this test the model regression was done. In the next section, the empirical results and the discussions will be shown.

\section{EMPIRICAL RESULTS AND DISCUSSION}

This section shows the results of VAR model, the specification tests, and the discussion of results. Table 5,shows the results of VAR model with the lag order (5).

Table5. Results of VAR model

\begin{tabular}{|c|c|c|c|c|c|c|}
\hline \multirow{2}{*}{ Response of } & \multicolumn{6}{|c|}{ Response to } \\
\hline & \multicolumn{2}{|c|}{ DLnGDP } & \multicolumn{2}{|c|}{ DLnBiofuels } & \multicolumn{2}{|c|}{ DLnOil } \\
\hline \multirow{3}{*}{ DLnGDP } & -0.7045 & & 3.3973 & & -1.7729 & \\
\hline & $(-10.55)$ & & (3.34) & & $(-3.93)$ & \\
\hline & 0.000 & $* * *$ & 0.001 & $\star * *$ & 0.000 & *** \\
\hline \multirow{3}{*}{ DLnBiofuels } & 0.1448 & & 0.5463 & & 0.4049 & \\
\hline & (13.86) & & $(3.50)$ & & $(4.00)$ & \\
\hline & 0.000 & $* * *$ & 0.000 & $* * *$ & 0.000 & *** \\
\hline \multirow{3}{*}{ DLnOil } & 0.2190 & & 1.8070 & & -0.8442 & \\
\hline & (7.02) & & $(6.71)$ & & $(-5.09)$ & \\
\hline & 0.000 & $* * *$ & 0.000 & $* * *$ & 0.000 & *** \\
\hline$N$ obs & \multicolumn{6}{|c|}{20} \\
\hline AIC & \multicolumn{6}{|c|}{-12.3084} \\
\hline HQIC & \multicolumn{6}{|c|}{-11.8419} \\
\hline SBIC & \multicolumn{6}{|c|}{-9.9186} \\
\hline
\end{tabular}

Notes: The Stata command var with the lag-order (5); *** denotes the significance of $1 \%$; the prefix ("D") denotes the first-differences of logarithms. 
The results of VAR indicated that the economic growth has a positive impact of $3.3973 \%$ in the consumption of biofuels and a negative impact of $-1.7729 \%$ in the consumption of oil. Furthermore, the consumption of biofuels has a positive impact of $0.144 \%$ in the economic growth and $0.4049 \%$ in the consumption of oil. Finally, the consumption of oil exerts a positive impact of $0.2190 \%$ in the economic growth and $1.8070 \%$ in the consumption of biofuels respectively. In order to observe the presence of causalities and their direction the Granger causality Walt test was used. Table 6 shows the results of Granger causality Walt test.

Table 6. Results of Granger causality Wald test

\begin{tabular}{|c|c|c|c|c|c|}
\hline \multicolumn{2}{|c|}{ Equation \ Excluded } & \multirow{2}{*}{$\begin{array}{c}\text { chi2 } \\
180.74\end{array}$} & \multirow{2}{*}{$\frac{\text { Df. }}{5}$} & \multicolumn{2}{|c|}{ Prob > chi2 } \\
\hline & DLnBiofuels & & & 0.000 & $\star \star *$ \\
\hline \multirow[t]{3}{*}{ DLnGDP } & DLnOil & 254.52 & 5 & 0.000 & $\star * *$ \\
\hline & ALL & 524.05 & 10 & 0.000 & $\star * *$ \\
\hline & DLnGDP & 68.657 & 5 & 0.000 & *** \\
\hline \multirow[t]{3}{*}{ DLnBiofuels } & DLnOil & 68.653 & 5 & 0.000 & $\star \star *$ \\
\hline & ALL & 122.14 & 10 & 0.000 & *** \\
\hline & DLnGDP & 29.276 & 5 & 0.000 & *** \\
\hline \multirow[t]{2}{*}{ DLnOil } & DLnBiofuels & 27.536 & 5 & 0.000 & $\star \star *$ \\
\hline & ALL & 54.708 & 10 & 0.000 & $* * *$ \\
\hline
\end{tabular}

Notes: The Stata command vargranger was used; ***, denotes the significance of $1 \%$; the prefixes ("D") denotes the first-differences of logarithms.

The Granger causality Wald test showed the presence of a bidirectional causality between all variables of this study. The test for normally distributed disturbances in order to identify the presence of normally distributed in the model was used. Table 7 evidences the results of this test.

Table 7. Results of test for normally distributed disturbances

\begin{tabular}{c|ccc}
\hline Equation & \multicolumn{1}{c}{ chi2 } & Df. & Prob > chi2 \\
\hline \multicolumn{4}{|c}{ Jarque-Bera test } \\
DLnGDP & 0.692 & 2 & 0.7076 \\
DLnBiofuels & 1.994 & 2 & 0.3690 \\
DLnOil & 0.110 & 2 & 0.9462 \\
ALL & 2.796 & 6 & 0.8339 \\
\hline DLnGDP & Skewness test & \\
DLnBiofuels & 0.599 & 1 & 0.4390 \\
DLnOil & 1.958 & 1 & 0.1617 \\
ALL & 0.109 & 1 & 0.7407 \\
DLnGDP & 2.667 & 3 & 0.4459 \\
DLnBiofuels & 0.093 & 1 & 0.7605 \\
DLnOil & 0.036 & 1 & 0.8499 \\
ALL & 0.001 & 1 & 0.9748 \\
\hline
\end{tabular}

Notes: The Stata command varnorm was used. The prefixes ("D") denotes the first-differences of logarithms.

The estimation results of this test indicated that the model has a normally distributed. To check the stability condition of VAR estimates, the Eigenvalue stability test was applied. Table 8 , shows the results of Eigenvalue stability test. 
Table 8. Eigenvalue stability test

\begin{tabular}{ccc}
\hline Eigenvalue & & Modulus \\
\hline $0.8711+$ & $0.7995 i$ & 1.1824 \\
$0.8711-$ & $0.7995 i$ & 1.1824 \\
-1.0844 & & 1.0844 \\
$-0.6517+$ & $0.8492 i$ & 1.0704 \\
$-0.6517-$ & $0.8492 i$ & 1.0704 \\
$0.9047+$ & $0.3999 i$ & 0.9891 \\
$0.9047-$ & $0.3999 i$ & 0.9891 \\
$-0.2592+$ & $0.9469 i$ & 0.9818 \\
$-0.2592-$ & $0.9469 i$ & 0.9818 \\
$-0.9277+$ & $0.3148 i$ & 0.9797 \\
$-0.9277-$ & $0.3148 i$ & 0.9797 \\
$0.3871+$ & $0.8980 i$ & 0.9779 \\
$0.3871-$ & $0.8980 i$ & 0.9779 \\
$0.1524+$ & $0.1197 i$ & 0.1938 \\
$0.1524-$ & $0.1197 i$ & 0.1938 \\
\hline
\end{tabular}

Notes: The Stata command varstable was used.

The results of Eigenvalue stability test indicated that the VAR model satisfies the stability condition. Moreover, to check the presence of endogenous variables in the VAR model, the Wald lag exclusion statistics test was used. Table 9,shows the results of Wald lag-exclusion statistics. 
Table 9. Results of Wald lag-exclusion statistics

\begin{tabular}{|c|c|c|c|c|}
\hline Lags & chi2 & & Prob > chi2 & \\
\hline \multicolumn{5}{|c|}{ Equation: DLnGDP } \\
\hline 1 & 41.6591 & 3 & 0.000 & *** \\
\hline 2 & 43.8116 & 3 & 0.000 & *** \\
\hline 3 & 195.5801 & 3 & 0.000 & *** \\
\hline 4 & 27.6073 & 3 & 0.000 & *** \\
\hline 5 & 313.995 & 3 & 0.000 & $\star \star \star *$ \\
\hline \multicolumn{5}{|c|}{ Equation: DLnBiofuels } \\
\hline 1 & 17.2261 & 3 & 0.001 & *** \\
\hline 2 & 35.0689 & 3 & 0.000 & *** \\
\hline 3 & 9.0638 & 3 & 0.028 & ** \\
\hline 4 & 42.5296 & 3 & 0.000 & *** \\
\hline 5 & 68.7305 & 3 & 0.000 & $\star * *$ \\
\hline \multicolumn{5}{|c|}{ Equation: DLnOil } \\
\hline 1 & 24.2670 & 3 & 0.000 & *** \\
\hline 2 & 17.4211 & 3 & 0.001 & $\star * *$ \\
\hline 3 & 21.4334 & 3 & 0.000 & *** \\
\hline 4 & 18.0819 & 3 & 0.000 & *** \\
\hline 5 & 33.1483 & 3 & 0.000 & $\star * *$ \\
\hline \multicolumn{5}{|c|}{ Equation: All } \\
\hline 1 & 131.8733 & 9 & 0.000 & $* * *$ \\
\hline 2 & 92.6794 & 9 & 0.000 & $* * *$ \\
\hline 3 & 278.6893 & 9 & 0.000 & *** \\
\hline 4 & 153.9139 & 9 & 0.000 & $* * *$ \\
\hline 5 & 490.9524 & 9 & 0.000 & $\star \star *$ \\
\hline
\end{tabular}

Notes: The Stata command varwle was used; ***,** denote significance of $1 \%$ and $5 \%$ respectively; The prefixes ("D") denotes the first-differences of logarithms.

The results of this test suggest that the VAR model is endogenous. According to what was mentioned in the previous section, the discussions of the results achieved through this research will proceed. The focus of this study analyzes the impact of consumption of biofuels on economic growth in Brazil.

The results of this study are consistent with several works (e.g. All-mulali et al.2016;Cetin,2016;Belaïd and Zrelli, 2016;Koçak and Şarkgüneşi, 2017; Choi and Yoo,2016; Shahid et al. 2014). Moreover, there are several justifications for the bidirectional relationship between consumption of biofuels and economic growth, consumption oil and economic growth, and consumption of biofuels and oil. So, the bidirectional nexus between consumption of biofuels and economic growth is confirmed by some studies (e.g. Fuinhas et al. 2017; Destek and Aslan, 2017; Attiaoui et al.2017). The enormous abundance of renewable energy sources in Brazil and in other Latin American countries stimulate the investments and renewable energy technologies and consequently exerts a positive impact on economic activity and energy consumption (Fuinhas et al. 2017). The bidirectional relationship between consumption of oil and economic growth is in line with several authors that studied this relationship (e.g. Mirza and Kanwal, 2017; Chang et al. 2017; Apergis and Payne, 2010). In the Latin America region, the consumption of fossil fuels (e.g. oil, coal, and gas) is the primary input for industry and agriculture that influences economic growth and consequently, energy consumption. Moreover, the bidirectional relationship between consumption of biofuels and oil is confirmed by Apergis and Payne (2012). The bidirectionality between consumption of renewable and fossil fuel energy is due to the substitutability effect between both energy sources. Indeed, this substitutability suggests that the development of renewable energy 
may provide relief from $\mathrm{CO} 2$ emissions generated by consumption of fossil fuels (Apergis and Payne, 2012). Finally, these results are an opportunity for policymakers to change the actual energy matrix with the introduction of more renewable energy sources in order to reduce the environmental degradation.

The next section will show the conclusions and solutions to increases the renewable energy participation in energy matrix of Brazil.

\section{CONCLUSIONS}

The nexus between consumption of biofuels and economic growth was studied. This study is focused in Brazil in the period of 1990-2015. TheVector Autoregressive (VAR) was used as methodology. The preliminary tests proved the existence of low-multicollinearity between the variables and unit root. The results of VAR model indicated that the economic growth has a positive impact of $3.3973 \%$ in the consumption of biofuels, and the consumption of biofuels exerts a positive impact of $0.144 \%$ in the economic growth. Additionally, the Granger causality test indicated the existence of a bidirectional nexus between both variables. So, the existence of a bidirectional relationship between economic growth and consumption of biofuels is due to the enormous abundance of renewable energy sources in Brazil that stimulates the investments in renewable energy technologies and consequently exerts a positive impact on economic activity and energy consumption.

\section{REFERENCES}

ATTIAOUI, I.; TOUMI, H.; AMMOURI, B.; GARGOURI, I. Causality links among renewable energy consumption, $\mathrm{CO} 2$ emissions, and economic growth in Africa: evidence from a panel ARDL-PMG approach. Environmental Science and Pollution Research, v.24 n.14, p.13036-13048,2017. doi: 10.1007/ s11356-017-8850-7.

AMASADO, G.; GUANNINI, C. Topics in Structural VAR Econometrics. Heidelberg: Springer, n.2, 1997. ISBN 978-3-642-60623-6.

APERGIS, N.; PAYNE, J.E.Renewable energy consumption and economic growth: Evidence from a panel of OECD countries. Energy Policy, v.38, n.1,p.656-660, 2010.doi.10.1016/j.enpol.2009.09.002.

APERGIS, N.;PAYNE, J.E. Energy consumption and growth in South America: Evidence from a panel error correction model. Energy Economics, v.32, n.6, p.1421-1426,2010.doi: 10.1016/j.eneco.2010.04.006.

APERGIS, N.; PAYNE, J.E. Renewable and non-renewable energy consumption-growth nexus: Evidence from a panel error correction model. Energy Economics, v.34, n.3, p.733-738,2012. doi: 10.1016/j. eneco.2011.04.007.

AL-MULALI, U.; SOLARIN, S.A.; OZTURK, I. Biofuel energy consumption-economic growth relationship: an empirical investigation of Brazil. Biofuels Bioproducts \& Biorefining, v.10, n.6, p.753-775, 2016. doi.10.1002/bbb.1675.

ACIKGOZ, B.; YILMAZER, M.; CINAR, S. Nexus between energy consumption and economic growth: the comparison of non-renewable natural resource poor and rich countries. International Journal Global Warming, v. 9, n.1 p.18-32, 2016. 
BARTELETT, M.S. Tests of significance in factor analysis. British Journal of Mathematical and Statistical Psychology, v.3, n.2, p.77-85, 1950.doi.10.1111/j.2044-8317. 1950.tb00285.x.

BELAÏD, F.; ZRELLI, M.H. Renewable and non-renewable electricity consumption, carbon emissions and GDP. Evidence from Mediterranean countries. Economic Research Forum, Working paper 1037, p.1-25,2016.

BP Statistical Review World Energy. Available in: < http://www.bp.com/en/global/corporate/energyeconomics/statistical-review-of-world-energy.html>.

CETIN, M.A. Renewable energy consumption-economic growth nexus in E-7 countries. Energy Sources, Part B: Economics, Planningand Policy, v.11, p.12, p.1180-1185,2016.doi.10.1080/15567249.2016.11 56195.

$\mathrm{CHOI}, \mathrm{H}-\mathrm{Y}$; $\mathrm{YOO}, \mathrm{S}-\mathrm{H}$. Oil consumption and economic growth: The case of Brazil. Journal Energy Sources, Part B: Economics, Planning and Policy, v.11, n. 8, p.705-710, 2016.doi.10.1080/15567249.2012.740144.

CHANG, T.; DEALE, D.; GUPTA, R.; HEFER, R.; INGLESI-LOTZ, R.; SIMO-KENGNE, B. The causal relationship between coal consumption and economic growth in the BRICS countries: Evidence from panel-Granger causality tests, Energy Sources, Part B: Economics, Planning, and Policy, v.12, n.2, p.138146, 2017.doi:10.1080/15567249.2014.912696.

DESTEK, M.A.; ASLAN, A. 2. Renewable and non-renewable energy consumption and economic growth in emerging economies: Evidence from bootstrap panel causality. Renewable Energy, p.111:757-763,2017. doi:10.1016/j.renene.2017.05.008.

FUINHAS, J.A.; MARQUES, A.C.; KOENGKAN, M. Are renewable energy policies upsetting carbon dioxide emissions? The case of Latin America countries. Environmental Science and Pollution Research, v.24, n.17, p.15044-15054,2017. doi: 10.1007/s11356-017-9109-z.

GREENE, W. H. Econometric Analysis. New Jersey: Prentice Hall, n.5, ISBN 0-13-066189-9,2002.

HAIR, J. F.; AANDERSON, R.; TATHAM, R. L.; BLACK, W. C. Multivariate Data Analysis. Upper Saddle River, NJ: Prentice Hall,2006.

HIRA, A.; OLIVEIRA, L.G. No substitute for oil? How Brazil developed its ethanol industry. Energy Policy, v.37, n.6, p.2450-2456, 2009.doi.10.1016/j.enpol.2009.02.037.

HAMILTON, J. D. Time Series Analysis. Princeton: Princeton University Press,1994.

HOOVER, K.D. Granger-causality. The New Classical Macroeconomics. Oxford: Basil Blackwell, p. 168-176, 1988. ISBN 0-631-14605-9.

JARQUE, C.M.; BERA, A.K. A test for normality of observations and regression residuals. International Statistical Review, n.2, p.163-172,1987.

KAISER, H. An index of factor simplicity. Psychometrika, n. 39, p.31-36,1974.

KOÇAK, E.; ŞARKGÜNEŞI, A. The renewable energy and economic growth nexus in Black Sea and Balkan countries. Energy Policy, v.100, p.51-57, 2017.doi.10.1016/j.enpol.2016.10.007. 
LANGEVELD, H.; DIXON, J.; KUELEN, H.V. Biofuel Cropping Systems: Carbon, Land and Food. Eartchscan from Routledge,2014. ISBN13: 978-1-315-88574-2.

LÜTLEPOHL, H.New Introduction to Multiple Time Series Analysis. New York: Springer,2005.

MIRZA, F.M.; KANWAL, A. Energy consumption, carbon emissions and economic growth in Pakistan: Dynamic causality analysis. Renewable and Sustainable Energy Reviews, n.72, p.1233-1240,2017. doi:10.1016/j.rser.2016.10.081.

SAPP, M.Brazilian biodiesel production up 85\% in 2015, 2016.Available in:http://www.biofuelsdigest. com/bdigest/2016/01/07/brazilian-biodiesel-production-up-85-in-2015.

SHAHID, A.U.; RATHORE, M.;ASLAM, N.; TARIQ, M.I.An Empirical Analysis of Energy Consumption and Economic Growth in Brazil.Journal of Economics and Development Studies, v.2, n. 2, p. 591-599,2014. ISSN: 2334-2382.

SIMS, C.A. Macroeconomics, and Reality. Econometrica, n.48, p.I-48,1980.

TERZI, H.; PATA, U. K. The effect of oil consumption on economic growth in Turkey. Doğuş Üniversitesi Dergisi, v.17, n. 2, p. 225-240,2016.

USDA (2015). Brazil: Anual Report: Biofuels - Ethanol and Biodiesel. Available in: < $<$ https://gain.fas.usda. gov/Recent\%20GAIN\%20Publications/Biofuels\%20Annual_Sao\%20Paulo\%20ATO_Brazil_8-4-2015.pdf>.

WATSON, M.W. Vector Autoregressions and Cointegration. Northwestern University and Federal Reserve Bank of Chicago, p.1-73,1994. Available in: <https://www.princeton.edu/ mwatson/papers/Watson hoe_1994.pdf>.

World Bank Database (WBD). Available in:< http://data.worldbank.org/ >. 